\title{
Morphological and molecular characterization of common European species of Adialytus (Hymenoptera: Braconidae: Aphidiinae) based on the mtCOI barcoding gene and geometric morphometrics of forewings
}

\author{
Saša S. STANKOVIĆ ${ }^{1}$, Andjeljko PETROVIĆ² ${ }^{2}$ MariJana IliĆ MilOŠEVIĆ ${ }^{1}$, Petr STARÝ ${ }^{3}$, Nickolas G. \\ KAVALLIERATOS ${ }^{4}$, VLADIMIR ŽIKIĆ ${ }^{1}$ and ŽELJKO TOMANOVIĆ ${ }^{2}$
}

\begin{abstract}
${ }^{1}$ Department of Biology and Ecology, Faculty of Sciences and Mathematics, University of Niš, Višegradska 33, 18000 Niš, Serbia; e-mails: sasasta@gmail.com; marijanailic83@yahoo.com; zikicvladimir@gmail.com

${ }^{2}$ Institute of Zoology, Faculty of Biology, University of Belgrade, Studentski trg 16, 11000 Belgrade, Serbia; e-mails: andjeljko@bio.bg.ac.rs; ztoman@bio.bg.ac.rs

${ }^{3}$ Institute of Entomology, Biology Centre, Czech Academy of Sciences, Branišovská 31, 37005 České Budějovice, Czech Republic; e-mail: stary@entu.cas.cz

${ }^{4}$ Laboratory of Agricultural Entomology, Department of Entomology and Agricultural Zoology, Benaki Phytopathological Institute, 8 Stefanou Delta str., Kifissia, 14561, Attica, Greece; e-mail: nick_kaval@hotmail.com
\end{abstract}

Key words. Hymenoptera, Braconidae, Adialytus, parasitoids, morphology, genetic diversity, key

\begin{abstract}
In this study three common European species of the genus Adialytus Förster, 1862 were examined: Adialytus ambiguus (Haliday, 1834), Adialytus salicaphis (Fitch, 1855) and Adialytus thelaxis (Starý, 1961). Molecular analysis involved the DNA barcoding of a region of the mitochondrial gene cytochrome oxidase I (COI). The genetic difference based on Kimura's two-parameter model for computing pairwise distances showed that $A$. thelaxis differs from both $A$. ambiguus and A. salicaphis by 4.9 and $6 \%$ on average, respectively. The genetic distance between $A$. ambiguus and A. salicaphis was $1.5 \%$ on average, suggesting that barcodes based on the COI gene are insufficiently informative for separating these two species. Geometric morphometrics analysis of forewing size and shape revealed statistically significant differences. The R1 vein on the forewing of $A$. ambiguus is more elongated than on the wings of A. salicaphis and A.thelaxis. The geometric morphometrics analysis of the forewings also revealed that $A$. salicaphis and $A$. thelaxis have much broader forewings, suggesting strong flight ability associated with their parasitizing arboricolous aphids. The distal part of the forewing of Adialytus ambiguus is narrower, which in this case suggests poor flight ability associated with parasitizing Sipha aphids on grasses. An illustrated key for identifying the European species of Adialytus is provided.
\end{abstract}

\section{INTRODUCTION}

The genus Adialytus Förster, 1862 belongs to the koinobiont endoparasitic wasps of the subfamily Aphidiinae (Hymenoptera: Braconidae). Adialytus resembles the genus Lysiphlebus Förster, 1862, but can be easily distinguished by its reduced wing venation. The forewings of the genus Adialytus lack the m-cu and r-m veins, present in most species of the genus Lysiphlebus (Starý, 1975) Fig. 1. The two genera can also be separated by the shape of the petiole, which is slender and elongated in Adialytus and triangular and short in Lysiphlebus (Starý, 1975). The genus Adialytus was established by Förster (1862) with the type species Adialytus tenuis Förster, 1862. However, it was later joined by Gahan (1910) to the genus Diaeretus Förster, 1862 on the basis of forewing venation. After redescription by Starý \& Schlinger (1967), Adialytus was recognized as a subgenus of Lysiphlebus, from which it differs in the previously mentioned characters. Finally, its generic rank was restored by Mackauer \& Starý (1967) and Mackauer (1968). It is usually considered as a genus of the subtribe Lysiphlebina Mackauer, along with the genera Lysiphlebus and Lysiphlebia Starý \& Schlinger, 1967. In later studies (Starý, 1970, 1975), Adialytus was still considered as a subgenus of Lysiphlebus. Furthermore, when the species Adialytus veronicaecola Starý, 1978, [originally Lysiphlebus (Adialytus) veronicaecola] was described, the subgeneric status was preserved (Starý \& Juchnevic, 1978). One year later, Starý \& Rakauskas (1979) described Adialytus balticus and confirmed the generic status of Adialytus. Currently, seven valid Adialytus species are recognized: A. ambiguus (Haliday, 1834), A. balticus Starý \& Rakauskas, 1979, Adialytus fuscicornis (Ashmead, 1891), Adialytus kaszabi Takada, 1979, A. salicaphis (Fitch, 1855), A. thelaxis (Starý, 1961) and A. veronicaecola (Starý, 1978). Adialytus ambiguus and $A$. salicaphis have the widest distribution, inhabiting the entire Holarctic (Mackauer \& Starý, 1967). The most common hosts of $A$. ambiguus are species of the genera Sipha Passerini, 1860 and Atheroides Haliday, 1838, both of which feed on Poaceae (Starý \& Rakauskas, 1979). There are also a few records of successful parasitization of Rhopalosiphum padi (Linnaeus, 1758) by $A$. ambiguus (Michelena et al., 2004; Stanković et al., 2013). Adialytus salicaphis parasitizes many species of the genus Chaitophorus Koch, 1854, which feed on poplars and willows (Takada, 1968; Shujauddin, 1978; Pike et al., 2000; Tomanović et al., 2006; Žikić et al., 2012). Adialytus thelaxis has been recorded so far from Asia and Europe, 
parasitizing species of the genus Thelaxes Westwood, 1840 (Starý, 1979; Kavallieratos et al., 2004; Žikić et al., 2012). The Nearctic species A. fuscicornis is recorded in Canada and the USA as a parasitoid of aphids of the genus Aphis (Linnaeus, 1758) (Smith, 1944; Pike et al., 2000). The remaining three species have much narrower distributions, especially A. balticus, which is recorded in Lithuania as a parasitoid of Dysaphis anthrisci Börner, 1950 on the root collar of Anthriscus sp. (Starý \& Rakauskas, 1979). Adialytus kaszabi is recorded only in Mongolia (Takada, 1979), and $A$. veronicaecola is restricted to Central Asia. The species $A$. veronicaecola parasitizes leaf-curling aphids of the genus Aphis (Starý \& Juchnevic, 1978; Rakhshani et al., 2012).

Here we investigate all the European species except $A$. balticus, for which we do not have any specimens (there is only type material in P. Starý's collection). All three species analyzed (A. ambiguus, A. salicaphis and A. thelaxis) are morphologically similar. According to the existing identification keys, these three species differ in the shape and length ratio of the flagellar segments and in their petioles and ovipositor sheaths (Starý \& Rakauskas, 1979; Mescheloff \& Rosen, 1990). However, the differences between species are unclear because the morphological traits are often subtle and inconspicuous. Two new phenotypes of $A$. ambiguus are reported from Iran (Rakhshani et al., 2012). These phenotypes are denoted as "A. arvicola" and " $A$. cf. ambiguus" and both are parasitoids of the genus Sipha, like the common A. ambiguus. However, they differ primarily in the length of the R1 vein, which is much shorter in these two phenotypes, especially in " $A$. arvico$l a$ ". These phenotypes of $A$. ambiguus further complicate the already difficult identification of Adialytus spp. In the past three decades, several identification keys for Adialytus species were published (Starý \& Rakauskas, 1979; Mescheloff \& Rosen, 1990; Rakhshani et al., 2012). However, the description in these keys of their coloration is vague and the measurements inconclusive.

Adialytus species are currently not considered to be economically important parasitoids. However, A. ambiguus parasitizes Sipha aphids, which are common on maize and wheat (Kavallieratos et al., 2004; Starý, 2006). Adialytus ambiguus was successfully introduced and established in Hawaii as a biocontrol agent of the sugarcane aphid Sipha flava (Forbes, 1884) (Culliney et al., 2003). Furthermore, A. salicaphis is an important parasitoid of Chaitophorus spp. in poplar nurseries (Tomanović et al., 2006; Žikić et al., 2012). An attempt was made in Chile to utilize $A$. salicaphis as a biocontrol agent against the poplar-feeding Chaitophorus leucomelas Koch, 1854, which is a nuisance because it produces large quantities of honeydew that contaminates roads and parked cars, but it failed, probably due to climatic conditions (Rodriguez et al., 2001). Living in or near agroecosystems, Adialytus spp. constitute an additional food source for predators and hyperparasitoids and thus has an important role in maintaining ecological stability in these habitats (Hågvar \& Hofsvang, 1991; Starý \& Pike, 1999).
The aim of the present research was to explore the genetic structure and morphological variability of European species of Adialytus (A. ambiguus, A. salicaphis and A. thelaxis) using partial sequences of the mitochondrial cytochrome oxidase subunit I (mtCOI) gene and geometric morphometrics analysis of forewing shape. We also provide a new identification key for the European species of Adialytus, based on the results of the geometric analysis and other morphological traits.

\section{MATERIAL AND METHODS}

All specimens of Adialytus were collected during 1970-2013 from several European countries, i.e., the Czech Republic, France, Greece, Lithuania, Montenegro, Serbia, Slovenia, Spain and Iran. The nomenclature of parasitoid morphology follows Sharkey \& Wharton (1997). The wasps analyzed along with their host associations are presented in Table 1. Aphid hosts were collected along with the plant material on which they fed and put into plastic containers covered with muslin cloth. The containers were placed in a growth cabinet kept at $22.5^{\circ} \mathrm{C}, 65 \% \mathrm{RH}$ and 16L: 8D (Kavallieratos et al., 2010) for 2-3 weeks until the emergence of the wasps. Specimens subjected to DNA analysis were kept in $96 \%$ ethanol. For the molecular analysis of the species we chose the mtCOI gene, which is widely used as a tool for discriminating closely related species. This barcoding gene is very informative for aphidiine parasitoids (Derocles et al., 2012; Mitrovski-Bogdanović et al., 2013; Petrović et al., 2013). This molecular marker is not only an efficient tool for use in the phylogenetic analysis of insects, but can also be used for rapid species identification (Hebert et al., 2003; Packer et al., 2009). Furthermore, molecular identification does not have to be invasive. The inspected specimens remain intact and can be used for further morphological study, in contrast to morphological analysis requiring dissection of the specimens.

Prior to molecular analysis, all genomic DNA material was extracted from the wasps using the KAPA Express Extract Kit according to the manufacturer's instructions. The barcoding region of the mtCOI gene was amplified using the primers LCO1490 and HCO2198 (Folmer et al., 1994). The PCR amplification of DNA was done in a $25 \mu \mathrm{l}$ volume containing $1 \mu \mathrm{l}$ of extracted DNA, $12.5 \mu 1$ of $1 \times$ KAPA2G Robust HotStart ReadyMix (which contains $2 \mathrm{mM} \mathrm{MgCl}$ in a concentration of $1 \mathrm{X}), 1.25 \mu \mathrm{l}(0.5 \mu \mathrm{m})$ of each primer and $9 \mu \mathrm{l}$ of molecular grade water. All PCR reactions took place in an Eppendorf Mastercycler ${ }^{\circledR}$ according to the following protocol: initial denaturation at $95^{\circ} \mathrm{C}$ for $5 \mathrm{~min} ; 35$ cycles consisting of $1 \mathrm{~min}$ at $94^{\circ} \mathrm{C}, 1 \mathrm{~min}$ at $54^{\circ} \mathrm{C}$ and $1.5 \mathrm{~min}$ at $72^{\circ} \mathrm{C}$; and a final extension at $72^{\circ} \mathrm{C}$ for $7 \mathrm{~min}$. Purification of the amplified samples was done using a QIAGEN QIAquick ${ }^{\circledR}$ PCR Purification Kit according to the manufacturer's instructions. Sequencing of the amplified DNA was performed by Macrogen Inc. (Seoul, South Korea).

Acquired sequences were edited using FinchTV (Geospiza, Inc., Seattle, WA) and prepared for alignment using Clustal $W$ incorporated in the MEGA5.2 software package (Tamura et al., 2011). To calculate the average genetic distance between obtained sequences, we used Kimura's two-parameter procedure of base substitution using the bootstrap method with 1000 replicates. Phylogenetic relationships were reconstructed using the maximum likelihood (ML) and maximum parsimony (MP) methods, also incorporated in MEGA5.2. One thousand bootstrap replicates were performed to assess branch support in the given trees. We obtained sequences from a total of 65 specimens of Adialytus (species, hosts and sampling data are given in Table 1). Specimens of Lysiphlebia mirzai Shujauddin, 1975, Lysiphlebus faba- 
TABLE 1. The list of specimens used in analysis. N-haplotype - number of different mitochondrial haplotypes per population. Nmorph. - number of specimens used in geometric morphometrics analysis. GeneBank (NCBI) accession numbers for each haplotype are given.

\begin{tabular}{|c|c|c|c|c|c|c|}
\hline Species & Host & Plant & Locality & N-haplotype & N-morph. & $\begin{array}{c}\text { GeneBank } \\
\text { accession no. }\end{array}$ \\
\hline A. ambiguus & Sipha maydis & Lolium perenne & GRC, Kyparissia & $1(\mathrm{~A} 8)$ & 15 & KJ719612 \\
\hline A. ambiguus & Sipha sp. & Zea mays & SRB, Niš, Popovac & $2(\mathrm{~A} 2, \mathrm{~A} 8)$ & 10 & $\begin{array}{l}\text { KJ719606 } \\
\text { KJ719612 }\end{array}$ \\
\hline A. ambiguus & Sipha maydis & Hordeum murinum & GRC, Kalamata & $1(\mathrm{~A} 6)$ & 13 & KJ719610 \\
\hline A. ambiguus & Sipha maydis & Bromus tectorum & IRN, Mane & $1(\mathrm{~A} 8)$ & - & KJ719612 \\
\hline A. ambiguus & Sipha sp. & Hordeum murinum & MNE, Bar & $1(\mathrm{~A} 8)$ & 10 & KJ719612 \\
\hline A. ambiguus & Sipha sp. & Digitaria sanguinalis & SRB, Lebane & - & 10 & - \\
\hline A. ambiguus & Sipha maydis & Hordeum murinum & FRA, Le Luc & - & 10 & - \\
\hline A. ambiguus & Sipha maydis & Plantago sp. & SRB, Tošin bunar & - & 12 & - \\
\hline A. ambiguus & Sipha sp. & Dactylis glomerata & SRB, Vlasina lake & $1(\mathrm{~A} 1)$ & - & KJ719605 \\
\hline A. ambiguus & Sipha sp. & Arrenantherum elatior & SRB, Tara mt. & $1(\mathrm{~A} 7)$ & 10 & KJ719611 \\
\hline A. ambiguus & Sipha maydis & Agropyrum repens & SRB, Kula & $1(\mathrm{~A} 2)$ & 8 & KJ719606 \\
\hline "A. arvicola" & Malaise Trap & & IRN, Qazvin, Reveskk & $1(\mathrm{~A} 4)$ & - & KJ719608 \\
\hline "A. arvicola" & Sipha maydis & Poa pratensis & LTU, Punciai & $2(\mathrm{~A} 6, \mathrm{~A} 8)$ & - & $\begin{array}{l}\text { KJ719610 } \\
\text { KJ719612 }\end{array}$ \\
\hline "A. arvicola" & Malaise Trap & & IRN, Qazvin, Koohin & $1(\mathrm{~A} 3)$ & - & KJ719607 \\
\hline "A. arvicola" & Sipha flava & Agropyrum repens & IRN, Kermanshah & $1(\mathrm{~A} 4)$ & - & KJ719608 \\
\hline "A. cf. ambiguus" & Sipha elegans & Triticum aestivum & IRN, Mashhad & $1(\mathrm{~A} 5)$ & - & KJ719609 \\
\hline "A. cf. ambiguus" & Sipha sp. & Hordeum sp. & IRN, Isfehan & 1 (A9) & - & KJ719613 \\
\hline "A. cf. ambiguus" & Sipha elegans & Gastridium phleoides & IRN, Isfehan & 1 (A9) & - & KJ719613 \\
\hline A. salicaphis & Chaitophorus populeti & Populus alba & ESP, Leida & $1(\mathrm{~S} 2)$ & - & KJ719615 \\
\hline A. salicaphis & Chaitophorus vitellinae & Salix alba & SVN, Zbilje & $2(\mathrm{~S} 3, \mathrm{~S} 5)$ & - & $\begin{array}{l}\text { KJ719616 } \\
\text { KJ719618 }\end{array}$ \\
\hline A. salicaphis & Chaitophorus leucomelas & Populus sp. & SVN, Zbilje & $1(\mathrm{~S} 7)$ & - & KJ719620 \\
\hline A. salicaphis & Chaitophorus leucomelas & Populus sp. & SVN, Zbilje & 1 (S8) & - & KJ719621 \\
\hline A. salicaphis & Chaitophorus sp. & Salix sp. & CZE, N. Dvur, Silesia & $1(\mathrm{~S} 8)$ & - & KJ719621 \\
\hline A. salicaphis & Chaitophorus sp. & Salix sp. & CZE, Ceske Budejovice & - & 10 & - \\
\hline A. salicaphis & Chaitophorus niger & Salix sp. & FRA, Antibes & - & 10 & - \\
\hline A. salicaphis & Chaitophorus salijaponicus & Salix alba & IRN, Shirvan & 1 (S6) & 14 & KJ719619 \\
\hline A. salicaphis & Chaitophorus populeti & Populus alba & IRN, Tehran & $1(\mathrm{~S} 8)$ & - & KJ719621 \\
\hline A. salicaphis & Chaitophorus populeti & Populus alba & SRB, Niš, Popovac & $1(\mathrm{~S} 4)$ & 15 & KJ719617 \\
\hline A. salicaphis & Chaitophorus sp. & Salix alba & IRAN, Isfehan & $2(\mathrm{~S} 6, \mathrm{~S} 8)$ & - & $\begin{array}{l}\text { KJ719619 } \\
\text { KJ719621 }\end{array}$ \\
\hline A. salicaphis & Chaitophorus sp. & Populus alba & SRB, Niš, Popovac & $1(\mathrm{~S} 4)$ & 11 & KJ719617 \\
\hline A. salicaphis & Chaitophorus niger & Salix fragilis & SRB, Niš, Popovac & $1(\mathrm{~S} 1)$ & 9 & KJ719614 \\
\hline A. salicaphis & Chaitophorus salicti & Salix caprea & SRB, Vlasina lake & $1(\mathrm{~S} 1)$ & 10 & KJ719614 \\
\hline A. salicaphis & Chaitophorus sp. & Salix caprea & SRB, Dukat mt. & $1(\mathrm{~S} 4)$ & 10 & KJ719617 \\
\hline A. salicaphis & Chaitophorus salicti & Salix caprea & SRB, Stara mt. B. zub & $2(\mathrm{~S} 1, \mathrm{~S} 3)$ & 10 & $\begin{array}{l}\text { KJ719614 } \\
\text { KJ719616 }\end{array}$ \\
\hline A. salicaphis & Chaitophorus populeti & Populus alba & IRN, Karadj & 1 (S6) & - & KJ719619 \\
\hline A. thelaxis & Thelaxes sp. & Quercus cerris & SRB, Lebane & $2(\mathrm{~T} 1, \mathrm{~T} 2)$ & 15 & $\begin{array}{l}\text { KJ719622 } \\
\text { KJ719623 }\end{array}$ \\
\hline A. thelaxis & Thelaxes sp. & Quercus ilex & MNE, Bečići & - & 9 & - \\
\hline A. thelaxis & Thelaxes sp. & Quercus cerris & SRB, Niš & $1(\mathrm{~T} 2)$ & 9 & KJ719623 \\
\hline A. thelaxis & Thelaxes sp. & Quercus castanifolia & IRN & - & 7 & - \\
\hline
\end{tabular}

rum (Marshall, 1896), Areopraon lepelleyi (Waterston, 1926) and Cotesia sp. Cameron, 1891 (Braconidae: Microgastrinae) were used as out group taxa. To calculate the genetic distance between the Adialytus species, the sequences of 29 specimens of $A$. ambiguus, 29 of $A$. salicaphis and seven of $A$. thelaxis were used in this analysis (Table 1). Of the 29 specimens of A. ambiguus, six belong to the " $A$. arvicola" phenotype and six to the " $A$. cf. ambiguus" phenotype (Rakhshani et al., 2012). To obtain phylogenetic trees with a clearer topology, we used one specimen per haplotype. The species $A$. ambiguus encompassed nine haplotypes (A1-A9), each consisting of 1 to 10 specimens, while A. salicaphis encompassed eight haplotypes (S1-S8), with 1 to 7 specimens per haplotype. Adialytus thelaxis was represented by only two haplotypes (T1-T2), one with one specimen and the other with six specimens (Table 1). All sequences were indel-free trimmed to a length of $619 \mathrm{bp}$ and in this form used for the phylogenetic analysis. 


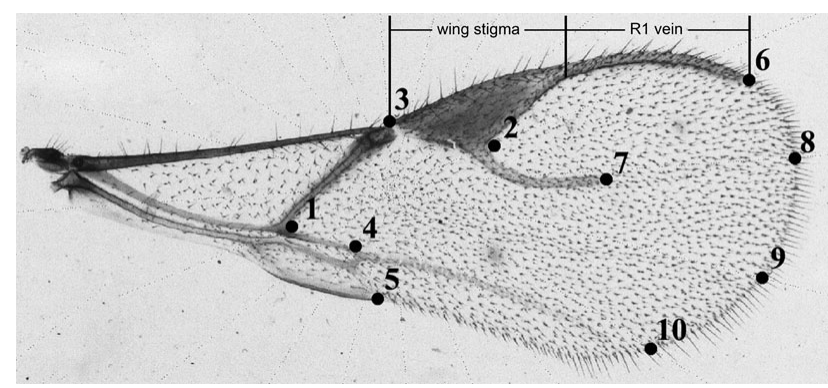

Fig. 1. Positions of the landmarks (1-7) and semi-landmarks (8-10) on the forewing of a species of Adialytus. The stigma and $\mathrm{R} 1$ vein are also marked.

The right forewings of female specimens were used to determine the variation in wing size and shape using a geometric morphometrics approach (Zelditch et al., 2004). In total, we used 237 specimens from 22 Adialytus populations; nine populations of $A$. ambiguus, nine of $A$. salicaphis and four of $A$. thelaxis (Table 1). In this study we defined a population as a set of specimens sampled at the same location on the same date. Most of the chosen phenotypes embodied 7 to 15 specimens per population. The wasps were dissected and mounted on microscope slides in Berlese solution. All wings were photographed using a Leica system DM2500 microscope with a Leica DFC490 digital camera (Leica Microsystems $^{\odot}$, Wetzlar, Germany) under the same magnification and at the same microscope settings. After digitalization, the wings were analyzed using a series of computer software packages.

Due to the reduced wing venation in the genus Adialytus, we used a combination of seven landmarks and three semi-landmarks (positions and definitions are given in Fig. 1) in order to analyze forewing size and shape.

Both landmarks and semi-landmarks were digitalized using Tps Dig2 software (Rohlf, 2005) by the same person (S. Stanković). Before placing the semi-landmarks, all wings were processed in the MakeFan6 (Sheets, 2003) program by adding star-shaped lines, which serve for consistent placement of semi-landmarks at equal angular displacements along the curves superimposed by generalized Procrustes analysis. Thus, all variations due to scale, position and orientation of landmark configurations were eliminated (Rohlf \& Slice, 1990; Bookstein, 1991). Superimposition of the semi-landmarks was done by allowing them to slide along curves bounded by landmarks, thus minimizing the Procrustes distances among the specimens analyzed (Bookstein, 1997).

Forewing size was computed as centroid size (CS), which represents the measure of size in geometric morphometrics and indicates the dispersion from the centroid of the landmark configuration. To explore the variation in size among forewings, we used analysis of variance (ANOVA) performed on centroid size, while for the shape variables we used multivariate analysis of variance (MANOVA) performed on eigenvalues of principal components, i.e., PC scores. The MorphoJ program was used to analyze and visualize shape changes described by canonical axes (Klingenberg, 2011). Principal component analysis (PCA) was used to analyze variability in wing shape among the specimens investigated. The differences in wing shape of the three Adialytus species was visualized using canonical variate analysis (CVA). The PC scores and centroid size (CS) were obtained using MorphoJ software. All statistical analyses were performed in the Statistica program package (Stat Soft Inc. 7.0).

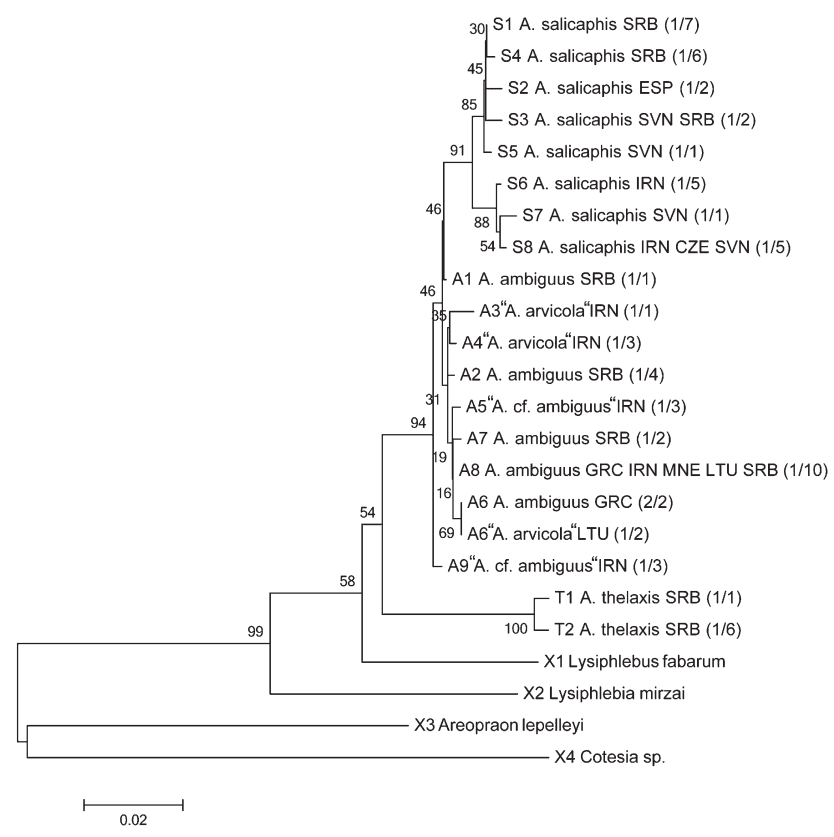

Fig. 2. Phylogenetic tree inferred using the maximum likelihood method. A discrete Gamma distribution was used to model the differences in evolutionary rate; Branches corresponding to partitions that were reproduced in less than $50 \%$ of the bootstrap replicates are collapsed. The percentage of replicate trees in which the associated taxa clustered together in the bootstrap test (1000 replicates) is shown next to the branches. Numbers in parentheses represent the number of specimens per given haplotype.

\section{RESULTS}

\section{Phylogenetic analysis}

The topology of the phylogenetic trees inferred using ML and MP methods reveals that the clade that includes $A$. thelaxis is clustered apart from the mutual clade of $A$. ambiguus and A. salicaphis. However, relationships between A. ambiguus and A. salicaphis are not clear. Both of the trees presented have almost the same topology (Figs 2, 3). The A1 and A9 haplotypes of A. ambiguus are separated from the clade, whereas all other haplotypes of $A$. ambiguus are clustered together and all those of $A$. salicaphis are grouped in the same clade (Figs 2, 3). The consistency of the A. salicaphis clade is well supported by both phylogenetic trees, in which more than 90 percent of the cases this branch was separated from the A. ambiguus branch. However, the topology of $A$. ambiguus on the phylogenetic trees is not so clear (Figs 2, 3). Haplotype A9 ( $A$. cf ambiguus) is positioned as a basal taxon to the mutual clade formed by $A$. ambiguus and A. salicaphis. Furthermore, the $A$. salicaphis clade has one sister taxon represented by haplotype A1, which is actually A. ambiguus. The analysis of genetic distances revealed that $A$. thelaxis differs from $A$. ambiguus on average by $4.9 \%$ and from $A$. salicaphis by $6 \%$. The average genetic distance between $A$. ambiguus and $A$. salicaphis is $1.5 \%$, but it ranges from 0.8 to $2.2 \%$. All specimens of $A$. ambiguus, which are denoted as " $A$. arvicola" phenotypes, are clustered together with other specimens of $A$. ambiguus and showed no particular grouping within the $A$. ambiguus clade. The genetic dis- 


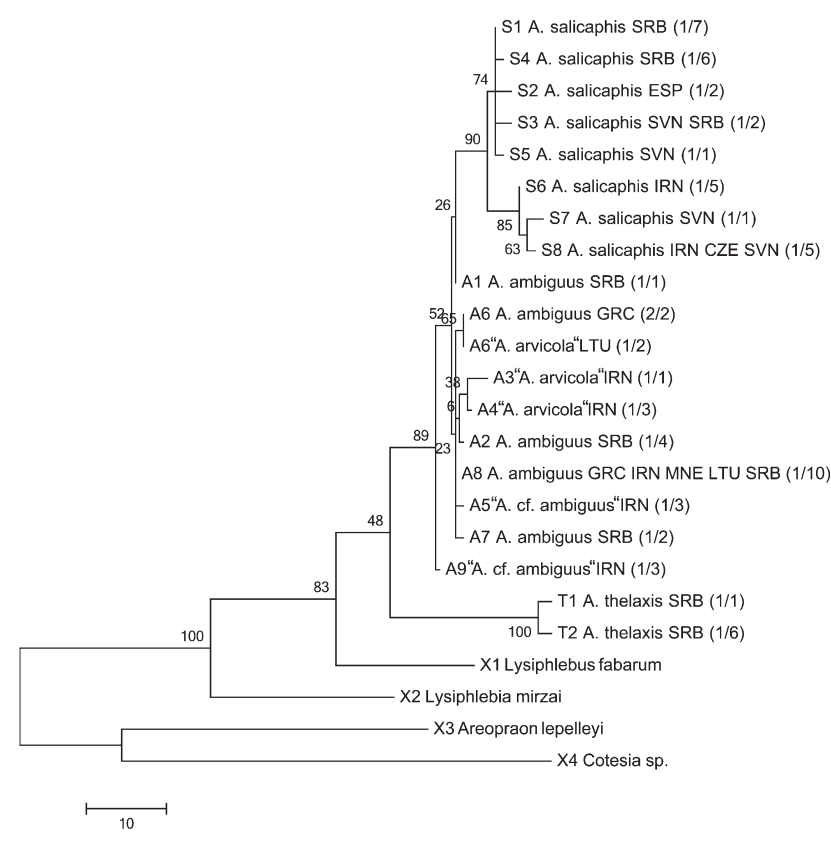

Fig. 3. The first of the 55 most parsimonious trees (length $=$ 249 ) with a consistency index of 0.691358 . Branches corresponding to partitions that were reproduced in less than $50 \%$ of the bootstrap replicates are collapsed. The percentage of replicate trees in which the associated taxa clustered together in the bootstrap test (1000 replicates) is shown next to the branches. Numbers in parentheses represent the number of specimens per given haplotype.

tance between phenotype "A. arvicola" and other $A$. ambiguus specimens ranges from 0 to $1 \%(0.3 \%$ on average). The situation is almost the same for phenotype " $A$. cf ambiguus": average genetic distance is $0.4 \%$ (range $0.2-1 \%$ ), but one of the haplotypes (A9) is not included in the main A. ambiguus clade (Figs 2,3). Although the topologies of the phylogenetic trees indicate that the $A$. salicaphis clade is closest to the $A$. ambiguus specimens mentioned above, the genetic distance between the A1 haplotype of $A$. ambiguus and all other specimens of $A$. ambiguus is $0.3 \%$ on average (range $0.2-0.8 \%$ ). However, the distance between the same haplotype (A1) and all specimens of $A$. salicaphis is $1.2 \%(0.8-1.7 \%)$. A similar situation exists with the A9 haplotype. The average genetic distance between this haplotype and all other specimens of $A$. ambiguus is $0.4 \%$ (0.3-1\%), while the distance from $A$. salicaphis is on average $1.6 \%$ (range $1.2-2.2 \%$ ). The average genetic distances within each particular group are: A. ambiguus: $0.4 \%, A$. salicaphis: $0.8 \%$ and $A$. thelaxis: $0.5 \%$.

\section{Geometric morphometrics}

The variation in the shape of the forewing of our material was determined using principal component analysis (PCA). Ordination of the specimens in morphospace defined by the first two principal axes is shown in Fig. 4. From the scatterplot it is evident that all specimens of $A$. ambiguus are grouped together on the right side of the PC1 axis, while all those of $A$. salicaphis and $A$. thelaxis are grouped on the left side and overlap. Overlapping is due to the similar length of the R1 vein.

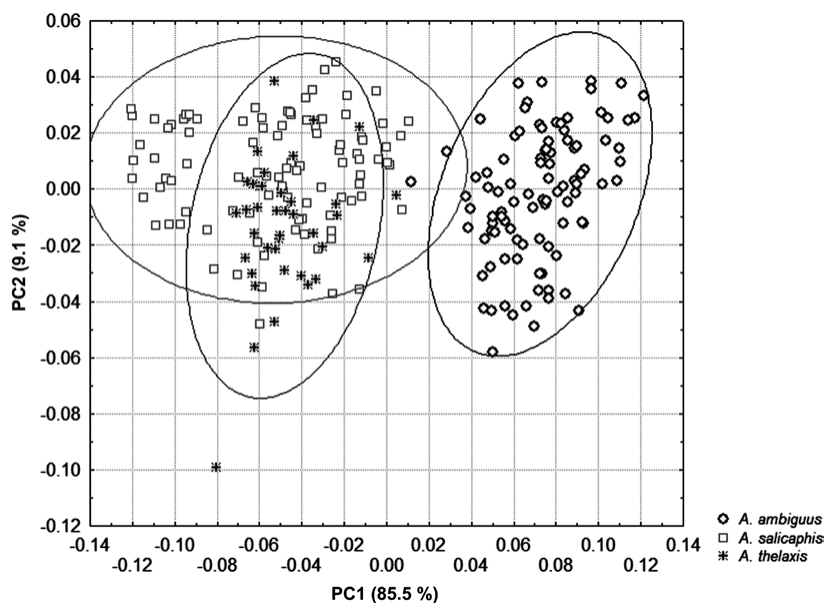

Fig. 4. Principal component analysis scatterplot of the results for the shape of the forewing: the PC1 axis accounts for $85.5 \%$ and PC2 axis for $9.1 \%$ of total variability. The confidence interval of the ellipses is $95 \%$.

Analysis of variance of the forewing size of Adialytus spp. showed marginally significant differences among the species (ANOVA: $\mathrm{F}_{(2,234)}=5.99 ; \mathrm{P}=0.002899$ ). Apart from forewing size, multivariate analysis of shape using PC scores also showed significant differences (MANOVA: Wilks' $\left.\lambda=0.026928 ; \mathrm{F}_{(32,438)}=69.72 ; \mathrm{P}<0.000001\right)$. As all differences were statistically significant, we performed a canonical variate analysis (CVA) in order to obtain a clearer distinction in terms of wing shape. In the morphospace defined by canonical axes, all three Adialytus spp. occupied discrete positions, with a clear distinction between all the species analyzed (Fig. 5).

Along the first canonical axis (CV1), which accounts for $82.91 \%$ of the total differences, $A$. ambiguus is separated from both $A$. salicaphis and $A$. thelaxis primarily by the length of the stigma and R1 vein on the forewing, which were described by landmarks 3 and 6 . It is also noticeable that the forewings of this species are narrower distally than in the other two species. This is evident from the shift in semi-landmarks 8,9 and 10 towards the center of the wing. The second canonical axis (CV2) explains the remaining variability and separates $A$. thelaxis from the other two species, especially from $A$. salicaphis, which it resembles in length of the R1 vein. Adialytus thelaxis has a slightly wider forewing proximally than A. salicaphis, which is evident from landmarks 1 and 2, as well as in the upper distal part, described by landmark 6 . However, the most conspicuous feature is the shape of the $\mathrm{R} 1$ vein. In A. salicaphis the upper right portion of the wing is more rounded than in $A$. thelaxis (landmark 6).

\section{Key to European species of Adialytus (based on females)}

1 Flagellomeres F3 and F4 about 1.5 times as long as wide. Three preapical flagellar segments square (Figs 6f, 7c) ....... 2

- Flagellomeres F3 and F4 $\geq 2$ times as long as wide. Three preapical flagellar segments not square (Figs 6d, 6e)........... 4

2 Ovipositor sheath sharply pointed (Fig. 6i) ............A. thelaxis - Ovipositor sheath broad at tip (Figs 6h, 7b) ........................ 3 

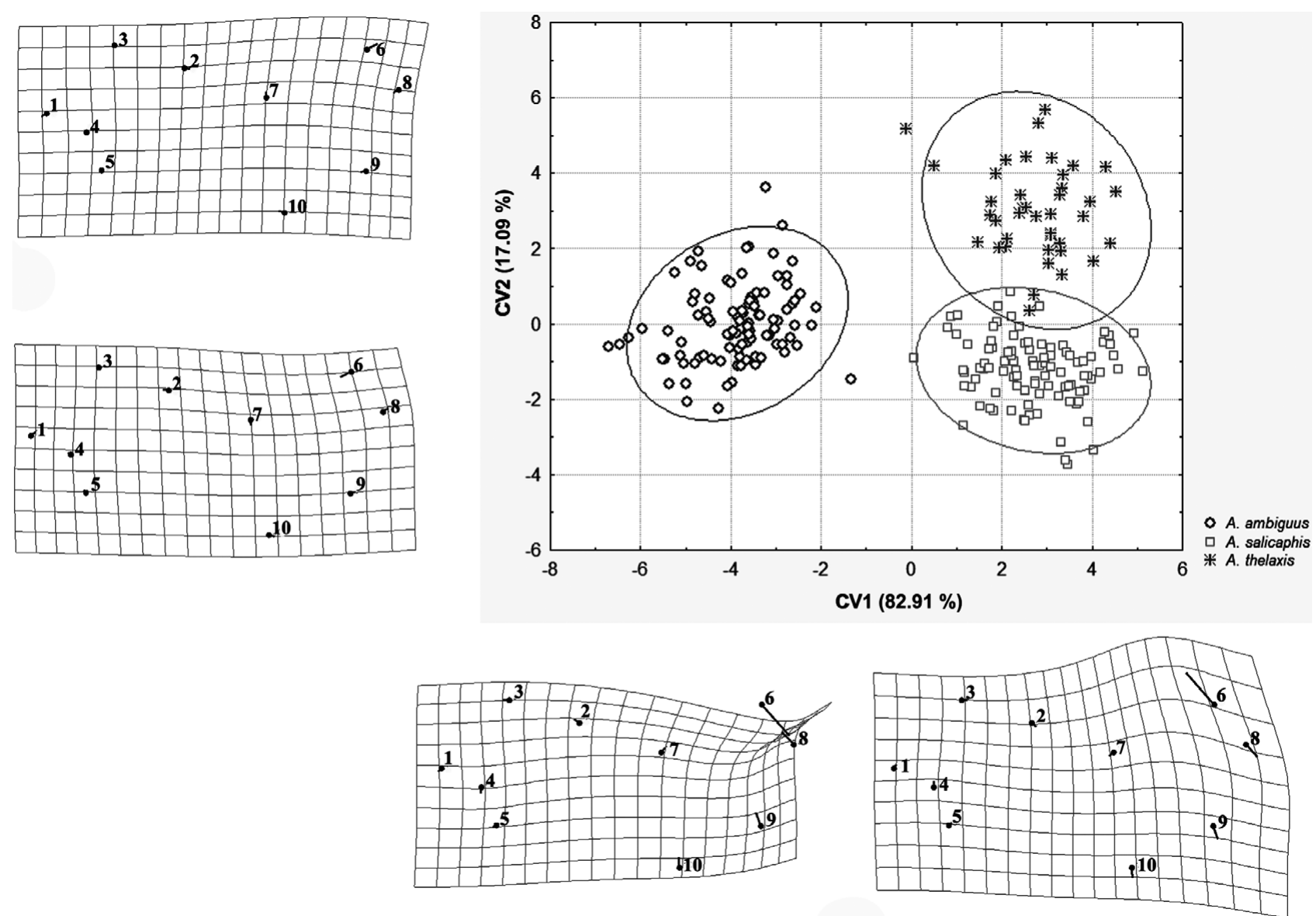

Fig. 5. Position of specimens of Adialytus in morphospace based on the shape of their forewings and defined by the first (CV1 = $82.91 \%)$ and second $(\mathrm{CV} 2=17.09 \%) \mathrm{CV}$ axis. The changes in wing shape are presented as thin-plate spline deformation grids. The scale factors for the transformation grid for both axes are -6 and 6 . The confidence interval of the ellipses is $95 \%$.

3 Dorsal outline of ovipositor sheath almost linear (Fig. 7b).... A. balticus

- Dorsal outline of ovipositor sheath strongly convex (Fig. 6h)

Ri............................................................... 4 ed at apex (Fig. 6g). Two divergent carinae present at base of propodeum (Fig. 6j) ......................................... A. ambiguus

- R1 vein as long as stigma (Fig. 6b). Ovipositor sheath broad at tip (Fig. 6h). Carinae absent or not clearly defined (Fig. $6 \mathrm{k})$....... A. salicaphis

\section{DISCUSSION AND CONCLUSIONS}

In this study we explored and identified variation in the morphology of the forewings of $A$. ambiguus, A. salicaphis and $A$. thelaxis. It is well known that wings of parasitoids are important in host location and mating behaviour (Godfray, 1994) and also a reliable taxonomical character (Starý, 1970). Geometric morphometrics of wing size and shape revealed some characters that are useful for identification at the species level. This method has proved to be very useful in resolving taxonomical problems of parasitoid species complexes (Baylac et al., 2003; Žikić et al., 2009; Mitrovski Bogdanović et al., 2013; Tomanović et al., 2013). The PCA analysis revealed that the length of the R1 vein varies between the species analyzed. Thus, this character can be used to distinguish $A$. ambiguus from the other two species analyzed. Although all specimens of $A$. ambiguus analyzed had a long R1 vein, which reached the upper right margin of the forewing, it is likely that the two phenotypes " $A$. arvicola" and "A. cf. ambiguus" described by Rakhshani et al. (2012) will not only be confused with other Adialytus ambiguus phenotypes, but also with $A$. salicaphis, if the identification is solely based on the length of the $\mathrm{R} 1$ vein. However, reliable identification of $A$. ambiguus is possible if a large number of specimens are available. The results of geometric morphometrics of the forewing also revealed that $A$. salicaphis and $A$. thelaxis have much broader forewings, suggesting they are strong fliers and this trait might be associated with their being parasitoids of arboricolous aphids. The distal part of the forewing of Adialytus ambiguus is narrower, which in this case suggests poor flight ability associated with parasitizing Sipha aphids on grasses. According to geometric morphometrics, A. salicaphis and $A$. thelaxis are morphologically more closely related to each other than either is to A. ambiguus.

In addition to the morphological differences between species of Adialytus, which are not conspicuous, we felt that it would be useful if they could be correctly identified using molecular analysis. However, the molecular analysis of these three species revealed a different picture of their phylogenetic relations. According to Kimura's two-pa- 

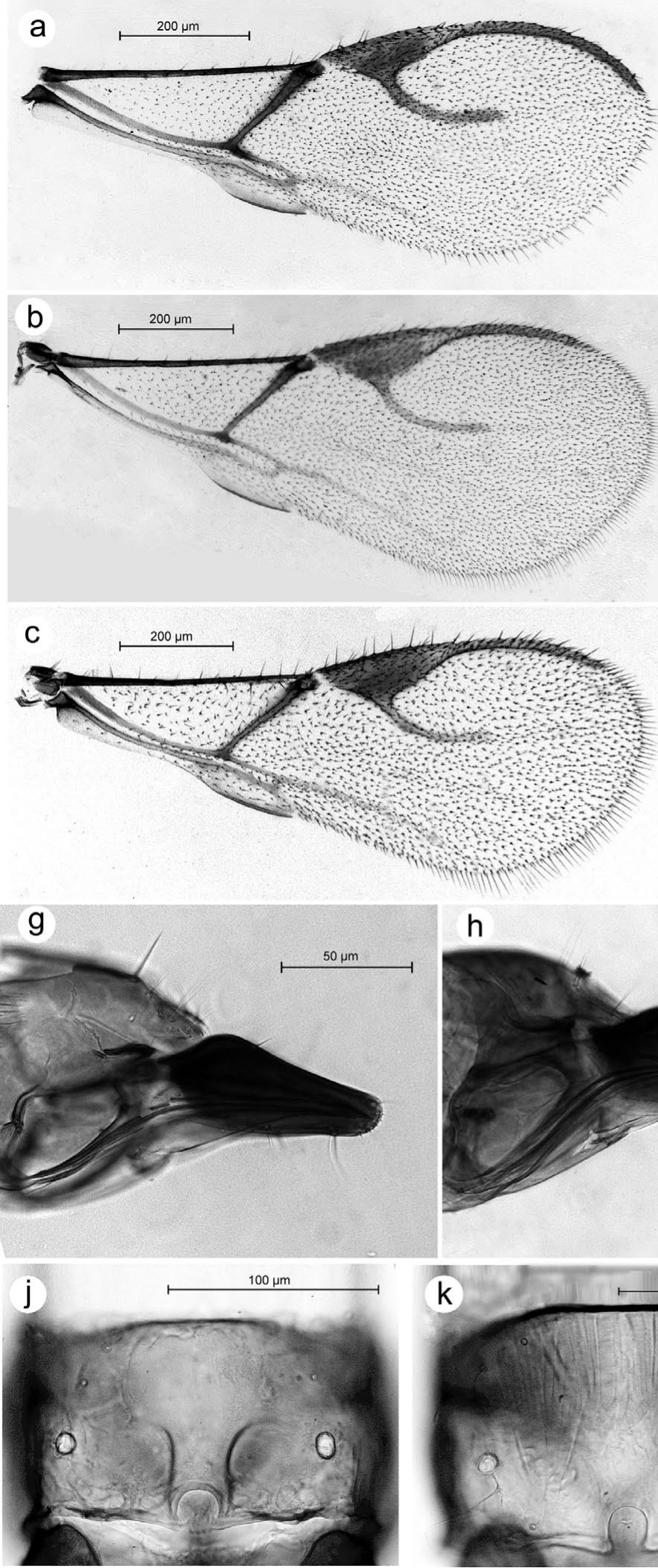

\section{$\mathrm{h}$}
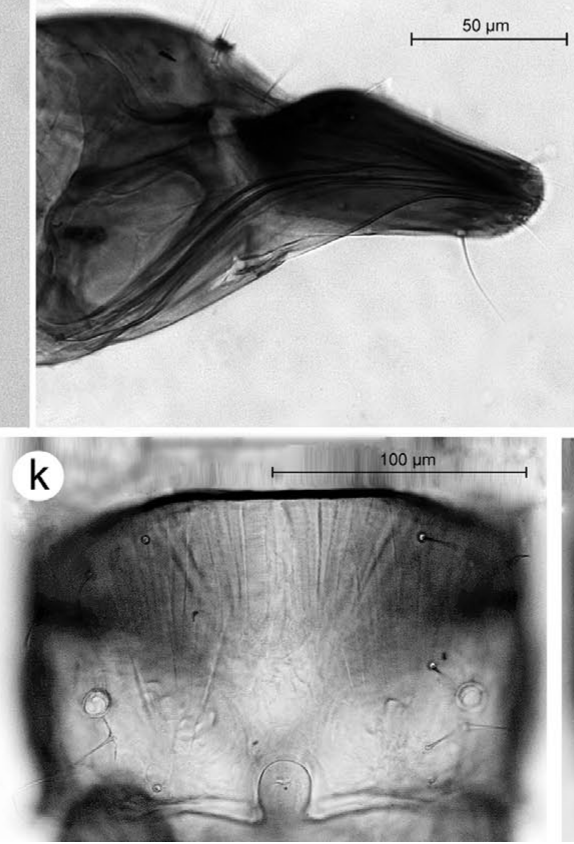
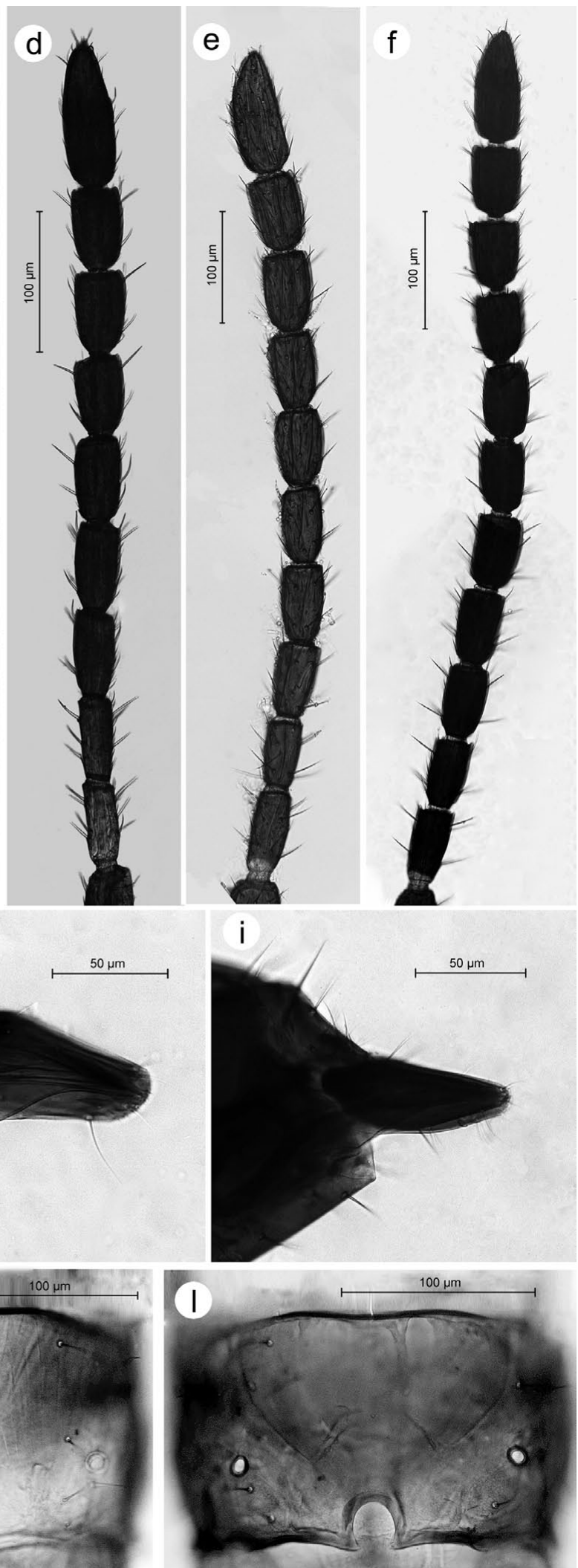

Fig. 6. Forewings, antennae (flagellomeres), ovipositor sheath and propodeum of the three species of Adialytus. A. ambiguus - a, d, $\mathrm{g}, \mathrm{j} ;$ A. salicaphis - b, e, h, k; A. thelaxis - c, f, i, 1 .

rameter model of pairwise distances among insects, $2 \%$ is enough to consider two entities as separate species (Packer et al., 2009; Kim et al., 2012). However, this percentage should not be used alone for the delimitation of species.
We strongly advocate the use of morphological traits and ecological data along with genetic distances, because the combination of these three methods can give more accurate information on species separation. The present study con- 


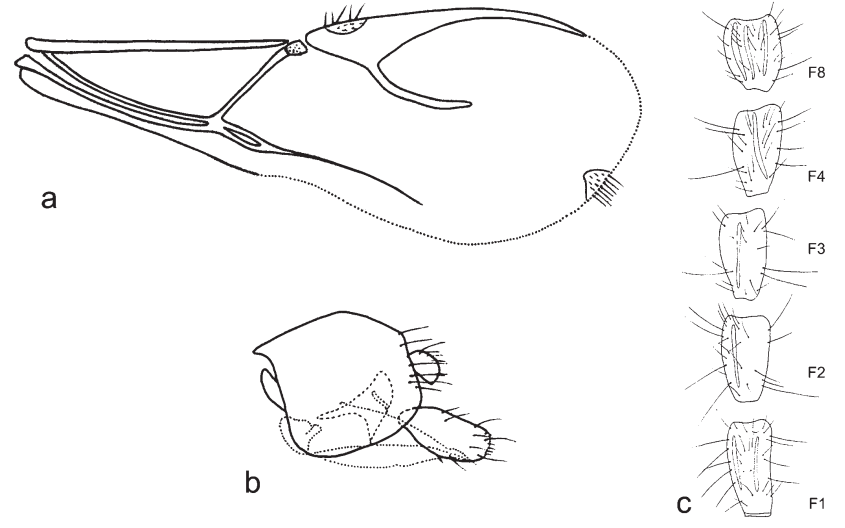

Fig. 7. Adialytus balticus: a - forewing; b-ovipositor; c - flagellar segments (after Starý \& Rakauskas, 1979).

firms that $A$. thelaxis is a "bona species" based on its genetic distance from both $A$. ambiguus and A. salicaphis, which is on average 4.9 and $6 \%$, respectively. This is clearly evident in both of the phylogenetic trees (Figs 2, 3) in which the separation of the $A$. thelaxis branch has the greatest "bootstrap" support. Although the phylogenetic reconstruction showed that $A$. salicaphis is a monophyletic group, the genetic distance based on the mtCOI gene of $1.5 \%$ (range from 0.8 to $2.2 \%$ ) between $A$. ambiguus and $A$. salicaphis indicates that in this case the mtCOI gene is not informative enough. The "bootstrap" support for separating the $A$. salicaphis branch is about $90 \%$, showing that this species is very consistently identified as monophyletic. However, A. ambiguus is a much more complex species, both genetically and morphologically. According to the topology of the phylogenetic trees there is relatively little support for the monophyly of this species. Haplotypes such as A1 seem to be close to A. salicaphis, whereas A9 is not included in the mutual clade consisting of these two species with a relatively high "bootstrap" support of about 50 percent. It seems that there is no congruence between the molecular and morphological variation within $A$. ambiguus. Haplotypes denoted as " $A$. cf ambiguus" and "A. arvicola" are not clustered in the same clade but rather scattered between other A. ambiguus haplotypes. A similar example is that of the Lysiphlebus fabarum aphidiine wasp group, where the mtCOI gene is not informative enough for the separation of three morphological and ecological different sexual/asexual taxa - L. fabarum, L. cardui and L. confusus (Derocles et al., 2012; Sandrock et al., 2011). According to Žurovcová et al. (2010) the mtCOI gene is not informative enough for separating species complexes of Adelgidae, but is informative enough to identify the genera. Both $A$. ambiguus and $A$. salicaphis parasitize aphids of the same subfamily (Chaitophorinae). However, A. thelaxis parasitizes aphids of the subfamily Thelaxinae indicating that this could be an evolutionary young complex. Adialytus ambiguus parasitizes aphids on herbaceous plants (Kavallieratos et al., 2004), while $A$. salicaphis attacks only aphids on trees, i.e., poplars and willows (Tomanović et al., 2006), which means that they have separate ecological niches.
Morphological variability of $A$. ambiguus together with the phenotypes " $A$. arvicola" and " $A$. cf ambiguus" is not reflected in genetic distance measured using the mtCOI gene. Both of these phenotypes are genetically very close or even identical to other specimens of A. ambiguus and are not grouped on the phylogenetic tree. Thus, we cannot state that these phenotypes are indeed different species, even though they are morphologically different (Rakhshani et al., 2012). The occurrence of these phenotypes also confirm that $A$. ambiguus is morphologically and genetically highly variable, suggesting that this particular species has great evolutionary plasticity.

This study reveals an apparent disparity between genetic traits on the one hand and morphological and ecological traits on the other. Incongruence between morphological and genetic traits is frequently recorded for parasitic wasps (Quicke \& Belshaw, 1999; Tomanović et al., 2013). For example, Tomanović et al. (2013) report that there is no relationship between variation in the barcoding area of the mtCOI gene and the level of morphological variation in wing shape in closely related species of the genus Aphidius Nees, 1818. Similarly, there is no relationship between morphology and genetic diversity in the Lysiphlebus fabarum species group (Sandrock et al., 2011). On the other hand, incongruence between ecological traits and genetic diversity has not been well studied within the subfamily Aphidiinae. An interesting example is the case of Aphidius microlophii Pennacchio \& Tremblay, 1987 and Aphidius ervi Haliday, 1834. Although, these species are morphologically similar, they are completely separated from an ecological point of view: $A$. microlophii parasitizes only Microlophium carnosum (Buckton, 1876) (Pennacchio \& Tremblay, 1986) and Wahlgreniella ossiannilssoni Hille Ris Lambers, 1949 (Petrović et al., 2006), while A. ervi parasitizes a large number of aphid hosts, but not the previous two species. Analyses of mtCOI sequences showed no differences between these two parasitoid species (Derocles et al., 2012), although it is known that there is significant reproductive isolation between them (Tremblay \& Pennacchio, 1988).

The results of this study revealed new relationships with respect to morphological and genetic variation in the genus Adialytus. Morphological differences in the shape of the forewings and patterns in wing venation, as well as other characters used in the key, had little support at the molecular level based on the mtCOI gene analyzed. However, each of the three species has a distinct ecology and a strong preference for different aphid hosts, which could be the main factor determining the morphological differences and consequent further separation of the species. Analysis of mating behaviour and reproductive isolation could provide additional information on the mechanism of speciation among species of the genus Adialytus.

ACKNOWLEDGEMENTS. This study was supported by grant III43001 (Ministry of Education, Science and Technological Development of the Republic of Serbia). Participation of P. Starý was funded by institutional support (RVO: 60077344). The authors wish to express their gratitude to E. Rakhshani (Department 
of Plant Protection, College of Agriculture, University of Zabol, Iran) for the loan of specimens and A. Ivanović (Institute of Zoology, Faculty of Biology, University of Belgrade, Serbia) for great help with the geometric morphometrics.

\section{REFERENCES}

Baylac M., Villemant C. \& Simbolotti G. 2003: Combining geometric morphometrics with pattern recognition or the investigation of species complexes. - Biol. J. Linn. Soc. 80: 89-98.

BooksteIn F.L. 1991: Morphometric Tools for Landmark Data: Geometry and Biology. Cambridge University Press, New York, $435 \mathrm{pp}$.

BooKSTEIN F.L. 1997: Landmark methods for forms without landmarks: Morphometrics of group differences in outline shape. - Med. Image Anal. 1: 225-243.

Culliney T.W., Nagamine W.T. \& Teramoto K.K. 2003: Introductions for biological control in Hawaii 1997-2001. _ Proc. Hawaiian Entomol. Soc. 36: 145-153.

Derocles S.A., Le Ralec A., Plantegenest M., Chaubet B., Cruaud C., CRuaud A. \& Rasplus J.Y. 2012: Identification of molecular markers for DNA barcoding in the Aphidiinae (Hym. Braconidae). - Mol. Ecol. Resour. 12: 197-208.

Folmer O., Black M., Hoen W., Lutz R. \& Vrijenhoek R. 1994: DNA primers for amplification of mitochondrial cytochrome $c$ oxidase subunit I from diverse metazoan invertebrates. - Mol. Mar. Biol. Biotechnol. 3: 294-299.

Förster A. 1862: Synopsis der Familien und Gattungen der Braconiden. - Verh. Naturh. Ver. Preuss. Rheinl. 19: 225-288.

Gahan A.B. 1910: Some synonymy and other notes on Aphidiinae. - Proc. Entomol. Soc. Wash. 12: 179-189.

Godfray H.C.J. 1994: Parasitoids: Behavioural and Evolutionary Ecology. Princeton University Press, Princeton, 488 pp.

HÅgvar E.B. \& Hofsvang T. 1991: Aphid parasitoids (Hymenoptera: Aphidiidae): biology, host selection and use in biological control. - Biocontr. News Inform. 12: 13-41.

Hebert P.D.N., Cywinska A., Ball S.L. \& deWaArd J.R. 2003 Biological identifications through DNA barcodes. - Proc. $R$. Soc. Lond. (B) 270: 313-321.

Kavallieratos N.G., Tomanović Ž., Starý P., Athanassiou C.G., Sarlis G.P., Petrović O., Niketić M. \& Veroniki M.A. 2004: A survey of aphid parasitoids (Hymenoptera: Braconidae: Aphidiinae) of Southeastern Europe and their aphid-plant association. - Appl. Entomol. Zool. 39: 527-563.

Kavallieratos N.G., Tomanović Ž., StarÝ P., ŽIKić V. \& Petrović-Obradović O. 2010: Parasitoids (Hymenoptera: Braconidae: Aphidiinae) attacking aphids feeding on Solanaceae and Cucurbitaceae crops in Southeastern Europe: Aphidiineaphid-plant associations and key. - Ann. Entomol. Soc. Am. 103: $153-164$.

Kim D.W., Yoo W.G., Park H.C., Yoo H.S., Kang D.W., Jin S.D., Min H.K., PAeK W.K. \& Lim J. 2012: DNA barcoding of fish, insects, and shellfish in Korea. - Genomics Inform. 10: 206-211.

Klingenberg C.P. 2011: MorphoJ: An integrated software package for geometric morphometrics. - Mol. Ecol. Resour. 11: 353-357.

Mackauer M. 1968: Pars 3. Aphidiidae. In Ferrière C. \& van der Vecht J. (eds): Hymenopterorum Catalogus (nova edito). Dr. W. Junk, The Hague, 103 pp.

Mackauer M. \& Starý P. 1967: World Aphidiidae. Index of Entomophagous Insects. Le Francois, Paris, 195 pp.

Mescheloff E. \& Rosen D. 1990: Biosystematic studies on the Aphidiidae of Israel (Hymenoptera: Ichneumonoidea) 3. The
Genera Adialytus and Lysiphlebus. - Isr. J. Entomol. 24: 3550 .

Michelena J.M., González P. \& Soler E. 2004: Parasitoides afdiinos (Hymenoptera, Braconidae, Aphidiinae) de pulgones de cultivos agrícolas en la Comunidad Valenciana. - Bol. San. Veg. Plagas 30: 317-326.

Mitrovski-Bogdanović A., Petrović A., Mitrović M., Ivanović A., Žikić V., Starý P., Vorburger C. \& Tomanović Ž. 2013: Identification of two cryptic species within the Praon abjectum group (Hymenoptera: Braconidae: Aphidiinae) using molecular markers and geometric morphometrics. - Ann. Entomol. Soc. Am. 106: 170-180.

Packer L., Gibbs J., Sheffield C. \& Hanner R. 2009: DNA barcoding and the mediocrity of morphology. - Mol. Ecol. Resour. (Suppl. 1) 9: 42-50.

Pennacchio F. \& Tremblay E. 1986: Biosystematic and morphological study of two Aphidius ervi Haliday (Hymenoptera: Braconidae) biotypes with the description of a new species. Boll. Lab. Entomol. Agr. Filippo Silvestri 43: 105-117.

Petrović A., Tomanović Ž. \& ŽIKIĆ V. 2006: Wahlgreniella ossiannilssoni Hille Ris Lambers, a new host for Aphidius microlophii Pennacchio and Tremblay (Hymenoptera: Braconidae: Aphidiinae). - Arch. Biol. Sci. 58: 41-42.

Petrović A., Mitrović M., Starý P., Petrović-Obradović O., Žikić V., Tomanović Ž. \& Vorburger C. 2013: Lysiphlebus orientalis (Hymenoptera, Braconidae), a new invasive aphid parasitoid in Europe - evidence from molecular markers. Bull. Entomol. Res. 103: 451-457.

Pike K.S., Starý P., Miller T., Graf G., Allison D., Boydston L. \& Miller R. 2000: Aphid parasitoids (Hymenoptera: Braconidae: Aphidiinae) of northwest USA. - Proc. Entomol. Soc. Wash. 102: 688-740.

Quicke D.L.J. \& Belshaw R. 1999: Incongruence between morphological data sets: An example from the evolution of endoparasitism among parasitic wasps (Hymenoptera: Braconidae). - Syst. Biol. 48: 436-454.

Rakhshani E., Starý P. \& Tomanović Ž. 2012: Species of Adialytus Förster, 1862 (Hymenoptera, Braconidae, Aphidiinae) in Iran: taxonomic notes and tritrophic associations. - ZooKeys 221: 81-95.

Rodriguez F.A., Rojas S.F., Lizarde K.L. \& Starý P. 2001: Internación a Chile de Adialytus salicaphis (Hym.: Aphidiidae), parasitoide del pulgón del álamo Chaitophorus leucomelas Koch (Hem.: Aphididae). In: Proceedings of XXIII Congr. Nac. de Entomologia, 5-7 Dec. 2001, Temuco, Chile. Sociedad Chilena de Entomología y Facultad de Ciencias Agronómicas de la Universidad de la Frontera.

Rohlf F.J. 2005: TpsDig, Digitize Landmarks and Outlines, version 2.05. Department of Ecology and Evolution. State University of New York at Stony Brook (http://life.bio.sunysb.edu/ morph/).

Rohlf F.J. \& SLice D.E. 1990: Extensions of the Procrustes method for the optimal superimposition of landmarks. - Syst. Zool. 39: $40-59$.

Sandrock C., Schirrmeister B. \& Vorburger C. 2011: Evolution of reproductive mode variation and host associations in a sexual-asexual complex of aphid parasitoids. - BMC Evol. Biol. 11: 348.

Sharkey M.J. \& Wharton R.A. 1997: Morphology and terminology. In Wharton R.A., Marsh P.M. \& Sharkey M.J. (eds): Manual of the New World Genera of the Family Braconidae (Hymenoptera). Special publication 1, International Society of Hymenopterists, Washington, DC, pp. 19-37.

SheETs H.D. 2003: IMP Suite (Integrated Morphometrics Package). Canisius College, Buffalo, NY. 
SHUJAUdDIN 1978: New record of Adialytus Förster (Hymenoptera: Aphidiidae) from India with comments on the validity of the genus. - J. Entomol. Res. 2: 160-162.

Sмiтн C.F. 1944: The Aphidiinae of North America (Braconidae: Hymenoptera). Ohio State University, Columbus, 153 pp.

Stanković S.S., Starý P. \& Mifsud D. 2013: Aphids and their parasitoids on the Canary grass, Phalaris canariensis in Malta (Hymenoptera, Braconidae, Aphidiinae). — Bull. Entomol. Soc. Malta 6: 137-141.

Starý P. 1970: Biology of Aphid Parasites (Hymenoptera: Aphidiidae) with Respect to Integrated Control. Dr. W. Junk, The Hague, 643 pp.

StARÝ P. 1975: The subgeneric classification of Lysiphlebus Forster 1862. - Annot. Zool. Bot. Bratislava 105: 1-9.

STARÝ P. 1979: Aphid Parasites (Hymenoptera, Aphididae) of the Central Asian Area. Dr. W. Junk, The Hague, 105 pp.

Starý P. 2006: Aphid Parasitoids of the Czech Republic (Hymenoptera: Braconidae: Aphidiinae). Academia, Praha, 430 pp.

StARÝ P. \& Juchnevic L.A. 1978: Aphid parasites (Hymenoptera: Aphidiidae) from Kazakhstan, USSR. - Pol. J. Entomol. 48: 523-532.

StarÝ P. \& PIKE K.S. 1999: Uses of beneficial insect diversity in agroecosystem management. Chapter 4. In Collins W.W. \& Qualset C.O. (eds): Biodiversity in Agroecosystems. CRC Press, Boca Raton, FL, pp. 49-67.

StARÝ P. \& RaKaUSKas R.P. 1979: Adialytus balticus sp.n., a parasitoid of Dysaphis anthrisci from the east Baltic (Hymenoptera, Aphidiidae; Homoptera, Aphididae). - Acta. Entomol. Bohemoslov. 76: 313-317.

Starý P. \& SChlinger E.S. 1967: A Revision of the Far East Asian Aphidiidae (Hymenoptera). Dr. W. Junk, The Hague, 204 pp.

TAKADA H. 1968: Aphidiidae of Japan (Hymenoptera). — Insecta Matsumur. 30: 67-124.

TAKADA H. 1979: Aphidiidae (Hymenoptera) from Mongolia. Folia Entomol. Hung. 32: 189-202.

Tamura K., Peterson D., Peterson N., Stecher G., Nei M. \& KUMAR S. 2011: MEGA5: Molecular evolutionary genetics analysis using maximum likelihood, evolutionary distance, and maximum parsimony methods. - Mol. Biol. Evol. 28: 2731-2739.

Tomanović Ž., Kavallieratos N.G., Starý P., Stanisavljević L., Petrović-Obradović O., Tomanović S. \& Jovanović S. 2006: Aphids and parasitoids on willows and poplars in southeastern Europe (Hemiptera: Aphidoidea; Hymenoptera: Braconidae, Aphidiinae). - J. Plant Dis. Prot. 113: 174-180.

Tomanović Ž., Kos K., Petrović A., Starý P., Kavallieratos N.G., ŽIKIĆ V., JaKŠE J., Trdan S. \& Ivanović A. 2013: The relationship between molecular variation and variation in the wing shape of three aphid parasitoid species: Aphidius uzbekistanicus Luzhetzki, Aphidius rhopalosiphi De Stefani Perez and Aphidius avenaphis (Fitch) (Hymenoptera: Braconidae: Aphidiinae). - Zool. Anz. 252: 41-47.

Tremblay E. \& Pennacchio F. 1988: Speciation in Aphidiinae (Hymenoptera). In Gupta V.K. (eds): Advances in Parasitic Hymenoptera Research. E.J. Brill, New York, pp. 139-146.

Zelditch M.L., Swiderski D.L., SheEts H.D. \& Fink W.L. 2004: Geometric Morphometrics for Biologists: A Primer. Elsevier Academic Press, New York, pp. 443.

Žıicić V., Tomanović Ž., Ivanović A., Kavallieratos N.G., Starý P., Stanisavljević L. \& Rakhshani E. 2009: Morphological characterization of Ephedrus persicae biotypes (Hymenoptera: Braconidae: Aphidiinae) in the Palaearctic. - Ann. Entomol. Soc. Am. 102: 1-11.

Žirić V., Ilić Milošević M., Stanković S., Petrović A., PetrovićObradović O., Kavallieratos N.G., Starý P. \& Tomanović Ž. 2012: Aphidiinae (Hymenoptera: Braconidae) of Serbia and Montenegro - tritrophic interactions. - Acta Entomol. Serb. 17: $83-105$

Žurovcová M., Havelka J., Starý P., Věchtová P., Chundelová D., JAROŠOVÁ A. \& KuČEROVÁ L. 2010: "DNA barcoding” is of limited value for identifying adelgids (Hemiptera: Adelgidae) but supports traditional morphological taxonomy. - Eur. J. Entomol. 107: 147-156.

Received February 11, 2014; revised and accepted July 25, 2014 Prepublished online October 16, 2014 